\title{
Glucagon receptor as a drug target: A witches' brew of eye of newt (peptides) and toe of frog (receptors)
}

\section{Derek J. Nunez MD | | David D'Alessio MD}

Division of Endocrinology, Metabolism and Nutrition, Duke Molecular Physiology Institute, Duke University School of Medicine, Durham, North Carolina Correspondence

Derek J. Nunez MD, Division of Endocrinology, Metabolism and Nutrition, Duke Molecular Physiology Institute, Duke University School of Medicine, Durham, NC. Email: derek.nunez@duke.edu

Glucagon has a noble history in the annals of metabolic disease, ${ }^{1}$ even though, to a layperson, insulin is its more famous counterregulatory partner. For decades medical students have been taught that glucagon raises blood glucose by increasing hepatic glucose output and that alleviation of hypoglycaemia is its primary function. ${ }^{2}$ Thus, inhibition of glucagon secretion ${ }^{3}$ or action ${ }^{4}$ are logical approaches to the development of therapeutics that improve glycaemic control in both type 2 and type 1 diabetes mellitus; indeed, this strategy has been pursued for nearly 4 decades.

The situation, however, is complex. The preproglucagon gene product can be cleaved at various points by specific prohormone convertases to yield several bioactive peptides, including glucagon, in a tissue-selective manner. ${ }^{1}$ Prohormone convertase 2 is expressed in pancreatic islets to generate mainly glucagon in $\alpha$ cells. By contrast, prohormone convertase $1 / 3$ processes proglucagon in the gut and brain to glucagon-like peptide-1 (GLP-1), glucagon-like peptide-2 (GLP-2), glicentin and oxyntomodulin. These boundaries are not absolute, however, and the relative abundance of these peptides in a tissue, and therefore its secretory potential, can vary depending on the differential expression of the processing enzymes. ${ }^{5}$ There is evidence that GLP-1 is expressed in pancreatic islets, ${ }^{6,7}$ while glucagon may be secreted by enteroendocrine cells in the gut. ${ }^{8}$ Enteroendocrine cells also express other peptides such as peptide-tyrosinetyrosine (PYY), ${ }^{9,10}$ and it now appears that secretion can be modulated by feedback inhibition by homotypic (GLP-1 reducing GLP-1 secretion) as well as heterotypic mechanisms (GLP-1 reducing PYY secretion). ${ }^{11,12}$

Glucagon receptor pharmacology is also multifaceted. The classic glucagon receptor ${ }^{13}$ is a member of the class B G-protein-coupled receptor (GPCR) family, ${ }^{14}$ and its structure has been reported recently. ${ }^{15,16}$ In classic experiments, glucagon was shown to elevate intracellular G-protein-coupled adenylyl cyclase activity and increase cAMP levels ${ }^{14}$; however, as with other GPCRs, the intracellular signal cascade can be modulated by other actions of G-proteins. In addition, the glucagon receptor can be desensitized after activation by internalization, and accessory proteins, such as $\beta$-arrestin and receptoractivity-modifying proteins (RAMPs), can modulate recycling of receptors to the cell surface. ${ }^{17}$ To add complexity to this brew, not only can glucagon signal via the classic glucagon receptor, ${ }^{14}$ but it can also interact with the "GLP-1" receptor with an affinity comparable to that of GLP-1 itself. ${ }^{18,19}$ Indeed, oxyntomodulin, essentially a glucagon molecule with a short C-terminal extension, can also signal both via the glucagon ${ }^{20}$ and GLP-1 receptors. ${ }^{21}$ Recently the oxyntomodulin-GLP-1 receptor interaction has been shown to exhibit biased agonism, ${ }^{22}$ and this may also apply to glucagon-GLP-1 receptor signalling.

Thus, glucagon fits into a complex "systems biology" network of ligands and targets ${ }^{23}$ in which it can interact with 2 types of receptors with the capacity to generate a range of exquisitely subtle responses via biased signal transduction, as well as having the potential to alter the secretion of other bioactive hormones. This is the broad context within which to consider the report in the current issue of Diabetes, Obesity and Metabolism by Kostic et al. ${ }^{24}$ on the results from an elegant first-time-in-human (FTIH) study with the glucagon receptor-blocking monoclonal antibody REGN1193. More specifically, previous studies with small molecule glucagon receptor antagonists and antisense molecules (Table 1) have uncovered good, bad and ugly aspects in humans (Table 2$)^{25}$; therefore, the essential question for drug development is whether these features can be separated sufficiently to open a wide therapeutic index, and allow safe long-term use. Small molecules targeting the glucagon receptor have both common structural elements and molecule-specific motifs that can confound the interpretation of adverse event profiles. Comparing the results from totally different molecular classes, small molecule-, antibody- and antisense-based approaches, therefore, allows some parsing of effects that can reasonably be attributed to mechanism-of-action vs those that may be related to moleculespecific "toxicity." Moreover, preclinical models such as glucagon 
TABLE 1 Summary of glucagon receptor blocking drugs evaluated in humans

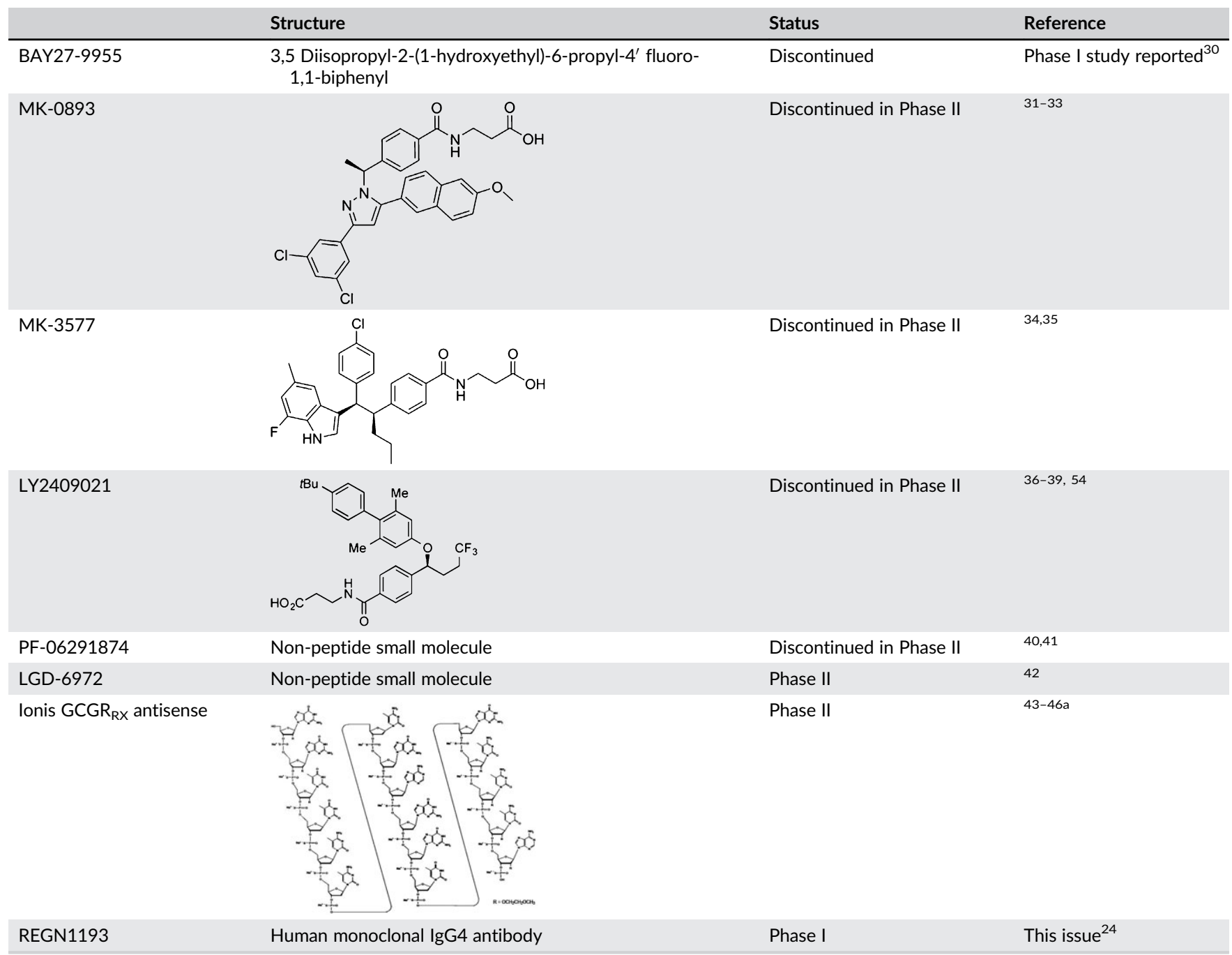

${ }^{a}$ Data from a Phase I study with a different antisense molecule, ISIS 325568, were reported by van Dongen et al. ${ }^{47}$

receptor knockout mice are also helpful, ${ }^{26}$ as are humans with lossof-function glucagon receptor mutations, ${ }^{27-29}$ especially when the biology and pharmacology are consistent and receptor mutants recapitulate the effects of glucagon receptor blockade in humans.

REGN1193 is a monoclonal antibody that blocks the glucagon receptor with a half maximal inhibitory concentration $\left(\mathrm{IC}_{50}\right)$ of $\approx 68 \mathrm{pM}$, as estimated from the inhibition of glucagon signalling in a cell-based reporter assay. This antibody binds with high affinity to mouse, rat, monkey and human glucagon receptors, allowing translation of pharmacodynamics across species. REGN1193 has been administered to diabetic and obese mice and diabetic monkeys ${ }^{48}$ and data from these studies were used to select doses for evaluation in the present FTIH study. In this randomized, placebo-controlled FTIH study, REGN1193 was administered by intravenous (i.v.) infusion to healthy subjects as single doses ranging from 0.05 to $0.6 \mathrm{mg} / \mathrm{kg}$. In addition to safety and pharmacokinetic measurements, the authors

TABLE 2 Comparison of adverse effects reported in human studies with glucagon receptor-blocking drugs

\begin{tabular}{|c|c|c|c|}
\hline Adverse events reported in human studies & REGN1193 & Glucagon receptor antagonists & Glucagon receptor antisense \\
\hline ALT/AST elevation & $\uparrow$ & $\uparrow$ & $\uparrow$ \\
\hline LDL cholesterol & No change & $\uparrow$ & No increase \\
\hline Hypoglycaemia ( $\leq 70$ mg/dL) & $\uparrow$ & $\uparrow$ & No change \\
\hline Blood pressure & No increase & $\uparrow$ & No increase \\
\hline Body weight & No change & $\uparrow$ & No change \\
\hline Hepatic steatosis & $?$ & $\uparrow$ & $?$ \\
\hline Circulating gluconeogenic amino acids ${ }^{a}$ & $\uparrow$ & $\uparrow$ & $?$ \\
\hline
\end{tabular}

Abbreviations: ALT, alanine aminotransferase; AST, aspartate aminotransferase; LDL, low density lipoprotein.

${ }^{a}$ In rodent studies, REGN1193, ${ }^{48}$ glucagon receptor antagonists ${ }^{49,50}$ and glucagon receptor knockout ${ }^{26}$ increase circulating amino acid levels, resulting in pancreatic islet $\alpha$-cell hyperplasia. ${ }^{51,52}$ 
TABLE 3 Summary of the pharmacodynamic effects of REGN1193 compared with those observed with other methods of modulating the glucagon and GLP-1 systems

\begin{tabular}{|c|c|c|c|c|c|c|}
\hline & REGN1193 & $\begin{array}{l}\text { Glucagon receptor } \\
\text { antagonists }\end{array}$ & $\begin{array}{l}\text { Glucagon } \\
\text { receptor } \\
\text { antisense }\end{array}$ & $\begin{array}{l}\text { Glucagon } \\
\text { receptor } \\
\text { knockout }\end{array}$ & $\begin{array}{l}\text { Glucagon } \\
\text { receptor } \\
\text { agonist }\end{array}$ & $\begin{array}{l}\text { GLP-1 } \\
\text { receptor } \\
\text { agonist }\end{array}$ \\
\hline $\begin{array}{l}\text { Glycaemic response to } \\
\text { glucagon challenge }\end{array}$ & $\downarrow$ & $\downarrow$ & $\downarrow$ & $\downarrow$ & NA & $?$ \\
\hline $\mathrm{HbA1c}$ & No data & $\downarrow \downarrow$ & $\downarrow \downarrow$ & $\downarrow$ & $?$ & $\downarrow$ \\
\hline $\begin{array}{l}\text { Circulating glucagon } \\
\text { concentration }\end{array}$ & $\uparrow$ & $\uparrow \uparrow$ & $\uparrow$ & $\uparrow \uparrow$ & $?$ & $\downarrow$ \\
\hline $\begin{array}{l}\text { Circulating insulin } \\
\text { concentration }\end{array}$ & $?$ & No change & $?$ & No change & $\uparrow$ (acute) & $\uparrow$ \\
\hline $\begin{array}{l}\text { Circulating C-peptide } \\
\text { concentration }\end{array}$ & $\begin{array}{l}\downarrow \text { post } \\
\text { glucagon } \\
\text { challenge }\end{array}$ & $\uparrow$ (fasting) & $?$ & $?$ & $\uparrow$ (acute) & $\uparrow$ \\
\hline $\begin{array}{l}\text { Circulating total GLP-1 } \\
\text { concentration }\end{array}$ & $\uparrow^{a}$ & $\uparrow^{a}$ & $\uparrow$ & $\uparrow \uparrow$ & $\downarrow^{53}$ & $\downarrow$ \\
\hline $\begin{array}{l}\text { Circulating GLP-2 } \\
\text { concentration }\end{array}$ & $\uparrow$ & $\uparrow$ & $?$ & $\uparrow$ & $?$ & $?$ \\
\hline $\begin{array}{l}\text { Glucose-dependent } \\
\text { insulinotropic peptide } \\
\text { (GIP) }\end{array}$ & No change & $?$ & $?$ & $?$ & $\downarrow^{53}$ & $?$ \\
\hline $\begin{array}{l}\text { Circulating PYY } \\
\text { concentration }\end{array}$ & $?$ & $?$ & $?$ & $?$ & $?$ & $\downarrow$ \\
\hline $\begin{array}{l}\text { Circulating bile acid } \\
\text { metabolites }\end{array}$ & $?$ & $\uparrow$ & $?$ & $?$ & $?$ & $?$ \\
\hline
\end{tabular}

Abbreviation: NA, not applicable.

a No consistent change in active GLP-1.

tracked pharmacodynamics directly using the inhibition of the hyperglycaemic response to a standardized glucagon challenge (0.8 $\mathrm{mg}$ i.v.). Onset-of-action was investigated using a pharmacologically active $0.3 \mathrm{mg} / \mathrm{kg}$ dose and the standardized glucagon stimulation test. Development of anti-drug antibodies was monitored over the 15week observation period.

REGN1193 exhibited markedly non-linear clearance, resulting in half-life estimates of 0.5 days for the $0.05 \mathrm{mg} / \mathrm{kg}$ dose to 4 days for the $0.6 \mathrm{mg} / \mathrm{kg}$ dose. Anti-drug antibody formation was unremarkable and did not contribute to the variable pharmacokinetics. The pharmacodynamic profile observed is summarized in Table 3. As expected from the non-clinical data, the higher doses of REGN1193 blocked the elevation of plasma glucose and C-peptide seen with the glucagon challenge, effects consistent with the reported actions of the non-peptide small molecule antagonists and antisense molecules listed in Table 1. The blocking effect of REGN1193 was evident as early as $6 \mathrm{~h}$ post-dose and persisted for at least 3 weeks. Previous work with the small molecule MK-0893 demonstrated predictable glucose-lowering in subjects with diabetes based on the degree of inhibition of glucagon-mediated hyperglycaemia ${ }^{31}$; however, it is essential that the effects of REGN1193 be tested in subjects with type 2 diabetes to estimate clinical effects and allow comparison with the $\geq 1 \%$ glycated haemoglobin $(\mathrm{HbA} 1 \mathrm{c}$ ) reductions observed with the small molecule antagonists ${ }^{31,32,34-36,40,54}$ and antisense molecules. ${ }^{43}$

While the "good" appears to be very good in terms of HbA1c reduction, inhibition of glucagon signalling in humans appears to carry liabilities (Table 2), and this has led to the termination of several drug development programmes in phase II or before (Table 1). It appears that all interventions in rodents that have interrupted glucagon receptor signalling have resulted in pancreatic islet $\alpha$-cell (and $\delta$-cell) hyperplasia to a greater or lesser extent ${ }^{26,49,50,55,56}$ related to the degree of interruption of a liver signal. ${ }^{57}$ Recently, a causal link has been established in glucagon receptor knockout mice between increased circulating amino acid levels, in particular glutamine, and the $\alpha$-cell hyperplasia. ${ }^{51,52}$ In this context, it is interesting to note that administration of $75 \mathrm{mg} / \mathrm{kg}$ REGN1193 for 8 weeks to normoglycaemic cynomolgus monkeys did not increase pancreatic $\alpha$-cell area, but did increase circulating amino acids, including glutamine; for comparison, $20 \mathrm{mg} / \mathrm{kg}$ was pharmacologically active in diabetic monkeys. ${ }^{48}$ This may be evidence of a difference in responsivity between murine and monkey islets or insufficient "dose $\times$ time" or a combination of both, but it is notable that humans with loss-of-function glucagon receptor mutations demonstrate $\alpha$-cell hypertrophy. ${ }^{27-29}$ The data relating to reversible increases in ALT and AST (without elevation of bilirubin) appear to be consistent across all glucagon receptor blocking modalities and there is now a report that LY240921 increases liver fat measured by MRI. ${ }^{37}$ As regards the elevation of LDL cholesterol initially observed with MK-0893 and MK-3577, ${ }^{32,34}$ this appears to correlate with the magnitude of glucose-lowering in people with type 2 diabetes, suggesting a mechanism-based association, perhaps through altered absorption of cholesterol. ${ }^{58}$ Initially, variable data were presented for LY240921 (no significant increase in LDL cholesterol after 12 or 24 weeks of treatment, ${ }^{36}$ elevation of total cholesterol ${ }^{54}$ ), but a more recent full publication clearly shows that 6 months of treatment with the compound increases circulating total cholesterol accompanied by a non-significant increase in LDL cholesterol compared with placebo. ${ }^{37}$ This is consistent with results using a different molecule, PF-06291874, in which the highest dose 
(150 mg) administered for 4 weeks significantly increased LDL cholesterol. ${ }^{40}$ No significant lipid effects have been described with the small molecule LGD- $6972^{42}$ or the antibody REGN1193, but it is not yet clear whether these are true differences from the other molecules or simply a reflection of shorter duration of dosing or the populations studied. LY240291 and MK-0893 increased body weight and blood pressure, ${ }^{31,32,37}$ and there were trends observed with PF$06291874,{ }^{40}$ but again these have not been observed with LGD-6972 or REGN1193. Interestingly, preliminary communications indicate that up to 14 weeks of dosing with the antisense lonis GCGRx was not associated with increases in LDL cholesterol, body weight or blood pressure, ${ }^{44}$ raising mechanistic questions about these phenomena.

Although the development of glucagon receptor antagonists is proving a thorny issue, it is yielding insights into the witches' brew of the glucagon-glucagon receptor system and related peptides. Kostic et al. ${ }^{24}$ describe actions of REGN1193 on various peptide biomarkers and these are compared across classes of drugs in Table 3. For example, the universal observation of elevated glucagon secretion when the receptor is blocked raises the possibility that there may be significant signalling through the GLP-1 receptor, ${ }^{18}$ as suggested by receptor knockout studies. ${ }^{19}$ Overlying this is the interesting possibility that there is differential feedforward stimulation (insulin/ C-peptide) and feedback inhibition (oxyntomodulin, glicentin, PYY, and even GLP-1 and GLP-2) of the secretion of bioactive peptides that may vary greatly depending on how much the receptor signalling is disturbed and whether this is being done in a "biased" manner. Some caution is prudent, therefore, when attributing the pharmacological and safety profiles of glucagon receptor blockers solely to their action at the hepatic glucagon receptor, and constant comparison across molecules is justified. As an example, circulating GLP-2, a peptide that stimulates growth of the gastrointestinal tract, ${ }^{59,60}$ is elevated when the glucagon receptor is blocked, indicating that longterm safety will require monitoring not only for the potential effects of absence of glucagon action, but also for actions attributable to accompanying changes in related bioactive peptides.

In conclusion, the road to a useful medicine based on blocking glucagon signalling appears steep and sticky, but the subtlety of the system may provide some hope that a golden key can be found if investment in drug discovery is maintained.

\section{Conflict of interest}

D. D.'A. has served as a consultant for Eli-Lilly and Co., Novo Nordisk Inc. and Janssen Pharmaceuticals Inc, has received research grant support from Merck and Co., and is an investigator in a clinical trial sponsored by Ligand Pharmaceuticals, Inc. D. J. N. has no conflict of interest to declare.

\section{Author contributions}

D.J.N. wrote the first draft. D.J.N. and D.D'A. reviewed the drafts and final submitted version.

\section{ORCID}

Derek J. Nunez (D) http://orcid.org/0000-0003-4704-3967

\section{REFERENCES}

1. Muller TD, Finan B, Clemmensen C, DiMarchi RD, Tschop MH. The new biology and pharmacology of glucagon. Physiol Rev. 2017;97(2): 721-766.

2. DAlessio $D$. The role of dysregulated glucagon secretion in type 2 diabetes. Diabetes Obes Metab. 2011;13(suppl 1):126-132.

3. Young A. Inhibition of glucagon secretion. Adv Pharmacol. 2005;52: 151-171.

4. Ali S, Drucker DJ. Benefits and limitations of reducing glucagon action for the treatment of type 2 diabetes. Am J Physiol Endocrinol Metab. 2009;296(3):E415-E421.

5. Nie Y, Nakashima M, Brubaker PL, et al. Regulation of pancreatic PC1 and $\mathrm{PC} 2$ associated with increased glucagon-like peptide 1 in diabetic rats. J Clin Invest. 2000;105(7):955-965.

6. Ellingsgaard H, Hauselmann I, Schuler B, et al. Interleukin-6 enhances insulin secretion by increasing glucagon-like peptide- 1 secretion from L cells and alpha cells. Nat Med. 2011;17(11):1481-1489.

7. Whalley NM, Pritchard LE, Smith DM, White A. Processing of proglucagon to GLP-1 in pancreatic alpha-cells: is this a paracrine mechanism enabling GLP-1 to act on beta-cells? J Endocrinol. 2011;211(1): 99-106.

8. Lund A, Bagger JI, Wewer Albrechtsen NJ, et al. Evidence of extrapancreatic glucagon secretion in man. Diabetes. 2016;65(3):585-597.

9. Egerod KL, Engelstoft MS, Grunddal KV, et al. A major lineage of enteroendocrine cells coexpress CCK, secretin, GIP, GLP-1, PYY, and neurotensin but not somatostatin. Endocrinology. 2012;153(12): 5782-5795.

10. Engelstoft MS, Egerod KL, Lund ML, Schwartz TW. Enteroendocrine cell types revisited. Curr Opin Pharmacol. 2013;13(6):912-921.

11. Naslund E, Bogefors J, Skogar S, et al. GLP-1 slows solid gastric emptying and inhibits insulin, glucagon, and PYY release in humans. Am J Physiol. 1999;277(3, pt 2):R910-R916.

12. Lin J, Hodge RJ, O'Connor-Semmes RL, Nunez DJ. GSK2374697, a long duration glucagon-like peptide-1 (GLP-1) receptor agonist, reduces postprandial circulating endogenous total GLP-1 and peptide YY in healthy subjects. Diabetes Obes Metab. 2015;17(10):1007-1010.

13. Jelinek LJ, Lok S, Rosenberg GB, et al. Expression cloning and signaling properties of the rat glucagon receptor. Science. 1993;259(5101): 1614-1616.

14. Authier F, Desbuquois B. Glucagon receptors. Cell Mol Life Sci. 2008;65(12):1880-1899.

15. Siu FY, He M, de Graaf $C$, et al. Structure of the human glucagon class B G-protein-coupled receptor. Nature. 2013;499(7459):444-449.

16. Zhang H, Qiao A, Yang D, et al. Structure of the full-length glucagon class B G-protein-coupled receptor. Nature. 2017;546(7657):259-264.

17. Cegla J, Jones BJ, Gardiner JV, et al. RAMP2 influences glucagon receptor pharmacology via trafficking and signaling. Endocrinology. 2017;158(8):2680-2693.

18. Moens K, Flamez D, Van SC, Ling Z, Pipeleers D, Schuit F. Dual glucagon recognition by pancreatic beta-cells via glucagon and glucagonlike peptide 1 receptors. Diabetes. 1998;47(1):66-72.

19. Ali S, Lamont BJ, Charron MJ, Drucker DJ. Dual elimination of the glucagon and GLP-1 receptors in mice reveals plasticity in the incretin axis. J Clin Invest. 2011;121(5):1917-1929.

20. Kosinski JR, Hubert J, Carrington PE, et al. The glucagon receptor is involved in mediating the body weight-lowering effects of oxyntomodulin. Obesity (Silver Spring). 2012;20(8):1566-1571.

21. Du X, Kosinski JR, Lao J, et al. Differential effects of oxyntomodulin and GLP-1 on glucose metabolism. Am J Physiol Endocrinol Metab. 2012;303(2):E265-E271.

22. Wootten D, Reynolds CA, Smith KJ, et al. The extracellular surface of the GLP-1 receptor is a molecular trigger for biased agonism. Cell. 2016;165(7):1632-1643.

23. Hwang JI, Yun S, Moon MJ, Park CR, Seong JY. Molecular evolution of GPCRs: GLP1/GLP1 receptors. J Mol Endocrinol. 2014;52(3):T15-T27.

24. Kostic AK, King AT, Yang F, et al. Human anti-glucagon receptor monoclonal antibody in normal healthy volunteers. Diabetes Obes Metab. 2017. DOI: 10.1111/dom.13075.

25. Sammons MF, Lee EC. Recent progress in the development of smallmolecule glucagon receptor antagonists. Bioorg Med Chem Lett. 2015;25(19):4057-4064. 
26. Vuguin PM, Charron MJ. Novel insight into glucagon receptor action: lessons from knockout and transgenic mouse models. Diabetes Obes Metab. 2011;13(suppl 1):144-150.

27. Zhou C, Dhall D, Nissen NN, Chen CR, Yu R. Homozygous P86S mutation of the human glucagon receptor is associated with hyperglucagonemia, alpha cell hyperplasia, and islet cell tumor. Pancreas. 2009;38(8):941-946.

28. Yu R. Pancreatic alpha-cell hyperplasia: facts and myths. J Clin Endocrinol Metab. 2014;99(3):748-756.

29. Larger E, Wewer Albrechtsen NJ, Hansen LH, et al. Pancreatic alphacell hyperplasia and hyperglucagonemia due to a glucagon receptor splice mutation. Endocrinol Diabetes Metab Case Rep. 2016. https:// doi.org/10.1530/EDM-16-0081.

30. Petersen KF, Sullivan JT. Effects of a novel glucagon receptor antagonist (Bay 27-9955) on glucagon-stimulated glucose production in humans. Diabetologia. 2001;44(11):2018-2024.

31. Ruddy M, Pramanik B, Lunceford J, et al. Inhibition of glucagoninduced hyperglycemia predicts glucose lowering efficacy of a glucagon receptor antagonist, MK-0893, in type 2 diabetes (T2DM). Diabetes. 2011;60(suppl 1):A85.

32. Engel S, Xu L, Andryuk P, Davies M, Amatruda J, Kaufman K. Efficacy and tolerability of MK-0893, a glucagon receptor antagonist (GRA), in patients with type 2 diabetes (T2DM). Diabetes. 2011;60(suppl 1):A85.

33. Xiong $\mathrm{Y}$, Guo J, Candelore MR, et al. Discovery of a novel glucagon receptor antagonist $\mathrm{N}-[(4-\{(1 S)-1-[3-(3,5-$ dichlorophenyl)-5-(6-methoxynaphthalen-2-yl)-1H-pyrazol-1-yl]ethyl\}phenyl)carbo nyl]-betaalanine (MK-0893) for the treatment of type II diabetes. J Med Chem. 2012;55(13):6137-6148.

34. Engel SS, Reitman ML, Xu L, et al. Glycemic and lipid effects of the short-acting glucagon receptor antagonist MK-3577 in patients with type 2 diabetes. Diabetes. 2012;61(suppl 1):A266.

35. Peng JZ, Denney WS, Musser BJ, et al. A semi-mechanistic model for the effects of a novel glucagon receptor antagonist on glucagon and the interaction between glucose, glucagon, and insulin applied to adaptive phase II design. AAPS J. 2014;16(6):1259-1270.

36. Kazda CM, Ding Y, Kelly RP, et al. Evaluation of efficacy and safety of the glucagon receptor antagonist LY2409021 in patients with type 2 diabetes: 12- and 24-week phase 2 studies. Diabetes Care. 2016;39(7):1241-1249.

37. Guzman CB, Zhang XM, Liu R, et al. Treatment with LY2409021, a glucagon receptor antagonist, increases liver fat in patients with type 2 diabetes. Diabetes Obes Metab. 2017; https://doi.org/10.1111/ dom.12958. [Epub ahead of print].

38. Kazda CM, Frias J, Foga I, et al. Treatment with the glucagon receptor antagonist LY2409021 increases ambulatory blood pressure in patients with type 2 diabetes. Diabetes Obes Metab. 2017;19(8): 1071-1077.

39. Kelly RP, Garhyan P, Raddad E, et al. Short-term administration of the glucagon receptor antagonist LY2409021 lowers blood glucose in healthy people and in those with type 2 diabetes. Diabetes Obes Metab. 2015;17(4):414-422.

40. Bergman A, Tan B, Somayaji VR, Calle RA, Kazierad DJ. A 4-week study assessing the pharmacokinetics, pharmacodynamics, safety, and tolerability of the glucagon receptor antagonist PF-06291874 administered as monotherapy in subjects with type 2 diabetes mellitus. Diabetes Res Clin Pract. 2017;126:95-104.

41. Kazierad DJ, Bergman A, Tan B, et al. Effects of multiple ascending doses of the glucagon receptor antagonist PF-06291874 in patients with type 2 diabetes mellitus. Diabetes Obes Metab. 2016;18(8): 795-802.

42. Vajda EG, Logan $\mathrm{D}$, Lasseter $\mathrm{K}$, et al. Pharmacokinetics and pharmacodynamics of single and multiple doses of the glucagon receptor antagonist LGD-6972 in healthy subjects and subjects with type 2 diabetes mellitus. Diabetes Obes Metab. 2017;19(1):24-32.
43. Ionis. Ionis pharmaceuticals reports positive data from phase 2 study of IONIS-GCGR Rx in patients with type 2 diabetes. 2017. http://ir. ionispharma.com/phoenix.zhtml?c=222170\&p=irol-newsArticle\&ID= 2233755.

44. Morgan E, Smith A, Watts L, et al. ISIS-GCGRRX, an antisense glucagon receptor antagonist, caused rapid, robust, and sustained improvements in glycemic control without changes in BW, BP, lipids, or hypoglycemia in T2DM patients on stable metformin therapy. (Abstract 109-LB). Diabetes. 2014;63(suppl 1):LB28.

45. Morgan E, Bethune C, Watts L, et al. Reduction of hepatic glucagon receptor expression with an antisense drug (ISIS-GCGR (RX)) increases total GLP-1 levels without affecting cholesterol or BP in normal subjects. Diabetologia. 2013;56(suppl 1):S280.

46. Luu KT, Morgan ES, Bhanot S, et al. Population pharmacokinetics and pharmacodynamics of IONIS-GCGRRX, an antisense oligonucleotide for type 2 diabetes mellitus: a red blood cell lifespan model. J Pharmacokinet Pharmacodyn. 2017;44(3):179-191.

47. van Dongen MG, Geerts BF, Morgan ES, et al. First proof of pharmacology in humans of a novel glucagon receptor antisense drug. J Clin Pharmacol. 2015;55(3):298-306.

48. Okamoto H, Kim J, Aglione J, et al. Glucagon receptor blockade with a human antibody normalizes blood glucose in diabetic mice and monkeys. Endocrinology. 2015;156(8):2781-2794.

49. Mu J, Jiang G, Brady E, et al. Chronic treatment with a glucagon receptor antagonist lowers glucose and moderately raises circulating glucagon and glucagon-like peptide 1 without severe alpha cell hypertrophy in diet-induced obese mice. Diabetologia. 2011;54(9):2381-2391.

50. Yang J, MacDougall ML, McDowell MT, et al. Polyomic profiling reveals significant hepatic metabolic alterations in glucagon-receptor (GCGR) knockout mice: implications on anti-glucagon therapies for diabetes. BMC Genomics. 2011;12:281.

51. Solloway MJ, Madjidi A, Gu C, et al. Glucagon couples hepatic amino acid catabolism to mTOR-dependent regulation of alpha-cell mass. Cell Rep. 2015;12(3):495-510.

52. Dean ED, Li M, Prasad N, et al. Interrupted glucagon signaling reveals hepatic alpha cell axis and role for I-glutamine in alpha cell Proliferation. Cell Metab. 2017;25(6):1362-1373.

53. Ranganath L, Schaper F, Gama R, et al. Effect of glucagon on carbohydrate-mediated secretion of glucose-dependent insulinotropic polypeptide (GIP) and glucagon-like peptide-1 (7-36 amide) (GLP-1). Diabetes Metab Res Rev. 1999;15(6):390-394.

54. Guzman CB, Zhang MX, Shankar SS, et al. Hepatic safety and efficacy of LY2409021, a novel selective glucagon receptor antagonist, in patients with T2D as an add-on treatment to metformin and sulfonylurea. Diabetes. 2016;65(suppl 1):A305.

55. Gelling RW, Du XQ, Dichmann DS, et al. Lower blood glucose, hyperglucagonemia, and pancreatic alpha cell hyperplasia in glucagon receptor knockout mice. Proc Natl Acad Sci U S A. 2003;100(3): 1438-1443.

56. Sloop KW, Cao JX, Siesky AM, et al. Hepatic and glucagon-like peptide1-mediated reversal of diabetes by glucagon receptor antisense oligonucleotide inhibitors. J Clin Invest. 2004;113(11):1571-1581.

57. Longuet C, Robledo AM, Dean ED, et al. Liver-specific disruption of the murine glucagon receptor produces alpha-cell hyperplasia: evidence for a circulating alpha-cell growth factor. Diabetes. 2013;62(4): 1196-1205.

58. Guan HP, Yang X, Lu K, et al. Glucagon receptor antagonism induces increased cholesterol absorption. J Lipid Res. 2015;56(11): 2183-2195.

59. Thulesen J, Hartmann B, Hare KJ, et al. Glucagon-like peptide 2 (GLP-2) accelerates the growth of colonic neoplasms in mice. Gut. 2004;53(8):1145-1150.

60. Drucker DJ, Yusta B. Physiology and pharmacology of the enteroendocrine hormone glucagon-like peptide-2. Annu Rev Physiol. 2014;76: 561-583. 